\title{
Physicochemical Properties of Membrane Adsorber from Palm Empty Fruit Bunch (PEFB) by Acid Activation
}

\author{
Nur Hidayah ${ }^{1, *}$, Muthia Elma ${ }^{2,3, * \mathbb{D}}$, Putri Vidiasari Darsono ${ }^{4}$, Isna Syauqiah ${ }^{2}$, Angelica Amenia ${ }^{3}$, \\ Daniel Guntur Laksana Putra ${ }^{3}$, Heru Renaldi Akbar ${ }^{3}$, Nurul Huda ${ }^{3}$ and Aulia Rahma ${ }^{3}$ \\ 1 Department of Industrial Engineering, Faculty of Science and Engineering, Sari Mulia University, \\ Jl. Pramuka No. 2, Banjarmasin 70238, Indonesia \\ 2 Department of Chemical Engineering, Faculty of Engineering, Lambung Mangkurat University, \\ Jl. A. Yani KM 36, Banjarbaru 70714, Indonesia; isnatk@ulm.ac.id \\ 3 Materials and Membranes Research Group (M2ReG), Lambung Mangkurat University, Jl. A. Yani KM 36, \\ Banjarbaru 70714, Indonesia; angelicamenia@mhs.ulm.ac.id (A.A.); DanielGLP@mhs.ulm.ac.id (D.G.L.P.); \\ HeruRA@mhs.ulm.ac.id (H.R.A.); Hudanurul@mhs.ulm.ac.id (N.H.); arahma@mhs.ulm.ac.id (A.R.) \\ 4 Pharmacy Department, Faculty of Health, Sari Mulia University, Jl. Pramuka No. 2, \\ Banjarmasin 70238, Indonesia; putrividiasari@gmail.com \\ * Correspondence: nurhidayah@unism.ac.id (N.H.); melma@ulm.ac.id (M.E.)
}

\section{check for}

updates

Citation: Hidayah, N.; Elma, M.; Darsono, P.V.; Syauqiah, I.; Amenia A.; Laksa Putra, D.G.; Akbar, H.R.;

Huda, N.; Rahma, A.

Physicochemical Properties of

Membrane Adsorber from Palm

Empty Fruit Bunch (PEFB) by Acid Activation. Membranes 2021, 11, 917 https://doi.org/10.3390/

membranes11120917

Academic Editor: Maria Grazia De Angelis

Received: 17 September 2021

Accepted: 19 November 2021

Published: 24 November 2021

Publisher's Note: MDPI stays neutral with regard to jurisdictional claims in published maps and institutional affiliations.

Copyright: (c) 2021 by the authors. Licensee MDPI, Basel, Switzerland. This article is an open access article distributed under the terms and conditions of the Creative Commons Attribution (CC BY) license (https:// creativecommons.org/licenses/by/ $4.0 /)$.
Abstract: A membrane adsorbent was successfully made from palm empty fruit bunches (PEFB), which was pyrolysed as physical activation. The effect of adding the impact of one-step catalyst (hydrochloric acid) and differences in the concentration on the characteristics and structure and deconvolution are investigated in this study. The results of the research have been successfully created and characterised using Fourier-Transform Infrared (FTIR), X-ray diffraction (XRD), BrunauerEmmett-Teller (BET) isotherm, and membrane morphology using SEM test. Membrane performance testing was carried out using a biogas flame test. The adsorber membrane was made by adding $\mathrm{NH}_{4} \mathrm{Cl}$ as a cationic surfactant, polyvinyl acetate (PVA), and polyethylene glycol (PEG) with a ratio of 1:3. The FTIR test has a functional group: $\mathrm{O}-\mathrm{H} ; \mathrm{C}-\mathrm{H}$ stretch; $\mathrm{C}=\mathrm{C}-\mathrm{C} ;$ Arly O-Strech; $\mathrm{C}-\mathrm{O}$. Adsorbent membrane with the addition of $0.5 \mathrm{M} \mathrm{HCl}$ catalyst had the highest ratio of $\mathrm{O}-\mathrm{H} / \mathrm{C}=\mathrm{C}-\mathrm{C}$ relative area of 4.33. The diffractogram shows an amorphous structure with (002) and (100) graph planes. Adsorber membrane with a concentration of $1.5 \mathrm{M} \mathrm{HCl}$ has formed amorphous structured fibre. The adsorber membrane with a concentration of $0.5 \mathrm{HCl}$ activator gave a surface area of $0.5345 \mathrm{~m}^{2} \mathrm{~g}^{-1}$ and a pore volume of $0.000983 \mathrm{~cm}^{3} \mathrm{~g}^{-1}$.

Keywords: palm empty fruit bunch; membrane adsorber; chemical activation; $\mathrm{HCl}$

\section{Introduction}

In recent decades, clean and renewable energy has become an interesting topic among researchers. Biogas is one of the products resulting from the bioconversion of organic materials used as a renewable energy fuel [1]. Biogas is generally produced from methanation of biomass and organic waste from anaerobic digestion sewage sludge, commercial compost, landfill, biomass gasification (thermochemical production process), anaerobic livestock manure with energy systems, and agro-food industrial processing facilities in mesophilic conditions $\left(35^{\circ} \mathrm{C}\right)$ and thermophilic conditions $\left(55^{\circ} \mathrm{C}\right)$. The composition of biogas generally consists of $45-55 \% \mathrm{CH}_{4}, 30-40 \% \mathrm{CO}_{2}, 5-15 \% \mathrm{~N}_{2}$, and $0-3 \% \mathrm{H}_{2}, 0-3 \%$ $\mathrm{CO}, 0-5 \% \mathrm{O}_{2}, 1-5 \% \mathrm{H}_{2} \mathrm{O}, 20-200$ ppm halogenated hydrocarbons, 0-100 ppm $\mathrm{H}_{2} \mathrm{~S}$ and 0-5 ppm $\mathrm{NH}_{3}$ [2]. Of course, various kinds of contaminants in landfill biogas have a good and bad influence on the quality of the biogas produced. Abatzoglou and Boivin (2009), in their journal, said that components such as $\mathrm{NH}_{3}$, sulfuric acid $\left(\mathrm{H}_{2} \mathrm{SO}_{4}\right)$, and siloxanes are impurity contaminants that can cause corrosive, health risks, environmental damage, and are dangerous during the combustion process because they can form microcrystalline silica [3]. 
However, not all contaminants in biogas are harmful; other components such as $\mathrm{CO}_{2}$, $\mathrm{H}_{2} \mathrm{O}, \mathrm{O}_{2}$, and $\mathrm{N}_{2}$ are considered valuable, as well as $\mathrm{O}_{2}$, which can help in some $\mathrm{H}_{2} \mathrm{SO}_{4}$ removal technologies. However, suppose the contaminant level is higher (almost equal to about $95 \%$ of the methane content). In that case, it can reduce the energy content of the biogas and result in a less than optimal quality of biogas production due to its low heating value [2]. Biogas with high impurity gas components such as $\mathrm{CO}_{2}, \mathrm{H}_{2} \mathrm{O}$, and $\mathrm{H}_{2} \mathrm{~S}$ can cause a decrease in calorific value. Therefore, biogas purification efforts are used to remove contaminants and achieve a distinctive biogas composition so that a high calorific value is achieved on combustion.

The biogas purification process can be carried out in several ways or methods, depending on the gas flow rate and economy [4]. According to Ryckebosch et al. (2011), biogas purification can be carried out in two main stages, namely removing trace components such as hydrogen sulphide $\left(\mathrm{H}_{2} \mathrm{~S}\right)$ and water vapour $\left(\mathrm{H}_{2} \mathrm{O}\right)$ which can cause corrosion in equipment and removing carbon dioxide gas to increase the heating value [5]. In general, the biogas purification process can be carried out physically, chemically, and biologically. Physical purification can be done by the adsorption method [6,7]. Biological purification uses bacteria as a decomposer of impurities. In comparison, chemical purification is one of them by using the activated absorption method [6]. Several purification technologies have been developed, including water scrubbing, organic solvent scrubbing, pressure swing adsorption, cryogenic separation process, chemical hydrogenation process, in situ and ex situ biological upgrading, chemoautotrophic methods, membrane separation, and others [1,2,5,8-12]. Membrane technology has several advantages: the separation process takes place at room temperature, can be carried out continuously, is variable, can be adjusted as needed, and the resulting membrane can be reused and is environmentally friendly because it does not cause a destructive impact on the environment. The membrane can also function as a specific filter because only certain molecules can pass through the membrane while the rest will be stuck on the surface [13].

There have been many studies regarding the purification of biogas by the membrane method [8,14-18]. Although the application is relatively easy, separating the membrane method weakens the wet or dry washing process. To overcome this, research has been carried out to integrate the membrane and adsorption based on the working principle of the filtration membrane and the adsorbent column. The union of these two methods is called the membrane adsorber [19]. The adsorber membrane is helpful in adsorption applications (purification) because it has a good retention capacity, especially at high loading rates. In addition, adsorber membranes require low production costs. In its operation, the adsorber membrane can capture molecules with a size of $<200 \mathrm{kDa}$ [20]. In the adsorber membrane, the type of adsorbent to be used as a raw material for the membrane has an important influence on capturing impurity gas or purified gas. These different types of adsorbents will provide other functional groups and adsorption properties of the membrane [19].

Indonesia is the world's number one producer of palm oil, with a total production of 48.4 million tons in 2019. This amount of production increased by $12.92 \%$ compared to the previous year, with sixty million hectares [21]. The value of Indonesian palm oil exports in 2019 reached USD 15.55 billion. Palm oil exports are the largest foreign exchange earner for the export sector of industrial products [22]. A large amount of waste also accompanies the promised economic value of the palm oil industry from the process. Processing one ton of fresh fruit bunches produces palm oil mill effluent (POME) as much as $583 \mathrm{~kg}$ [23].

Meanwhile, the types of waste at $t$ generated include mesocarp fibre (MF), shells, and empty bunches of $144 \mathrm{~kg}$, $64 \mathrm{~kg}$, and $210 \mathrm{~kg}$, respectively. PEFB are the most considerable solid waste produced in this process [24]. PEFB has a high biomass content. However, the utilisation of PEFB is limited to a mixture of animal feed, fertiliser, boiler fuel, or even just buried. Improper handling of PEFB can cause air pollution from leachate and carbon dioxide gas emissions from the combustion process [25]. Therefore, efforts are needed to utilise this waste, and its abundance becomes a more promising product. 
Palm empty fruit bunch contains many nutrients, organic matter and physically consists of various kinds of fibre with a composition of about $36.81 \%$ cellulose, $27.01 \%$ hemicellulose, and $22.60 \%$ lignin [26]. With high organic content, palm empty fruit bunch can be used as activated charcoal in the separation process using the adsorption method. There have been many studies that have proven the effectiveness of adsorbents from oil palm empty fruit bunches [27-35].

The test results of activated carbon of oil palm empty fruit bunches show the presence of carbon groups and surface area with an average BET test of more than $500 \mathrm{~m}^{2} / \mathrm{g}$ [27]. This supports the use of PEFB-activated carbon as raw material for membrane manufacture. It was reported that PEFB waste had been used as a membrane matrix to absorb motor exhaust gases. PEFB waste is first synthesised into activated carbon and cellulose acetate and then mixed to form a membrane matrix [36]. Another study also reported PEFB activated carbon as an additive for the manufacture of ceramic membranes. It is suspected that the addition of activated carbon from oil palm empty fruit bunches can increase the surface area in the BET test [37].

This study aimed to prepare and characterise membrane adsorber from empty palm fruit bunches using a one-step acid-base catalyst. This study used physical-chemical activation methods such as physics using pyrolysis. In contrast, chemical activation was produced through chemical activators using hydrochloric acid $(\mathrm{HCl})$ concentrations of $0.5,1$, and $1.5 \mathrm{M}$. The effectiveness of membrane adsorber will be seen from the Fourier-Transform Infrared (FTIR), X-ray diffraction (XRD), Brunauer-Emmett-Teller (BET) isotherm, and membrane morphology using the SEM test.

This work shows that adding an acid catalyst to the adsorber membrane for activated carbon extract of palm empty fruit bunches can improve the performance of the absorption effectiveness through the formation of a larger absorption area compared to a membrane that only undergoes physical activation. This work determines the possible application of adsorber membranes in the gas separation process, especially biogas. The performance of the membrane was seen through the FTIR test, $\mathrm{N}_{2}$ physisorption, to determine the surface area and pore diameter. XRD and SEM analyses were conducted to see the formation of amorphous structures.

\section{Materials and Methods}

\subsection{Chemical and Materials}

OPEFB membrane adsorber was prepared using chemicals and materials such as palm empty fruit branches (PEFB) from PT. Kharisma Alam Persada, South Kalimantan, Indonesia; isopropyl alcohol (2-propanol, Merck, Singapore); ammonium chloride $\left(\mathrm{NH}_{4} \mathrm{Cl}\right.$, Merck); polyethylene glycol 400 (PEG 400); polyvinyl alcohol (PVA); filter paper; and deionised water (DI water Merck).

\subsection{Preparation and Activation of Activated Carbon PEFB}

Palm empty fruit bunches adsorber membrane was made by pyrolysis process as physical activation and hydrochloric acid $(\mathrm{HCl})$ as a chemical activator. PEFB were collected from oil palm plantations that have been washed by freshwater and dried for seven days under the sunlight. After a week, the PEFB were physically activated using pyrolysis apparatus at $500{ }^{\circ} \mathrm{C}$ for $30 \mathrm{~min}$. Subsequently, the activated PEFB was mashed and sieved with 200-400 mesh to obtain the uniform extent. This powder can be called a physical activation adsorber. The activation process was done by adding hot distilled water to 3 beaker glasses which already contained $20 \mathrm{~g}$ of PEFB powder until all parts were wet.

Furthermore, the activator solution used is hydrochloric acid $(\mathrm{HCl})$, added $100 \mathrm{~mL}$ with variations of $0.5,1$, and $1.5 \mathrm{M}$ in each beaker and evaporated to dry on a hot plate at a temperature of $120^{\circ} \mathrm{C}$. After that, we pour $200 \mathrm{~mL}$ of distilled water into the three containers and leave it on a hot plate for $30 \mathrm{~min}$ at $50{ }^{\circ} \mathrm{C}$. Next, it is filtered with Whatman filter paper and washed 15 to 20 times using distilled water until normal. The result of filtering is in the form of a solid residue. Then, the powder is dried in an oven at $60^{\circ} \mathrm{C}$, 
and the activated powder is weighed. Schematic set-up fabrication of membrane adsorber PEFB can be seen in Figure 1, as follows.

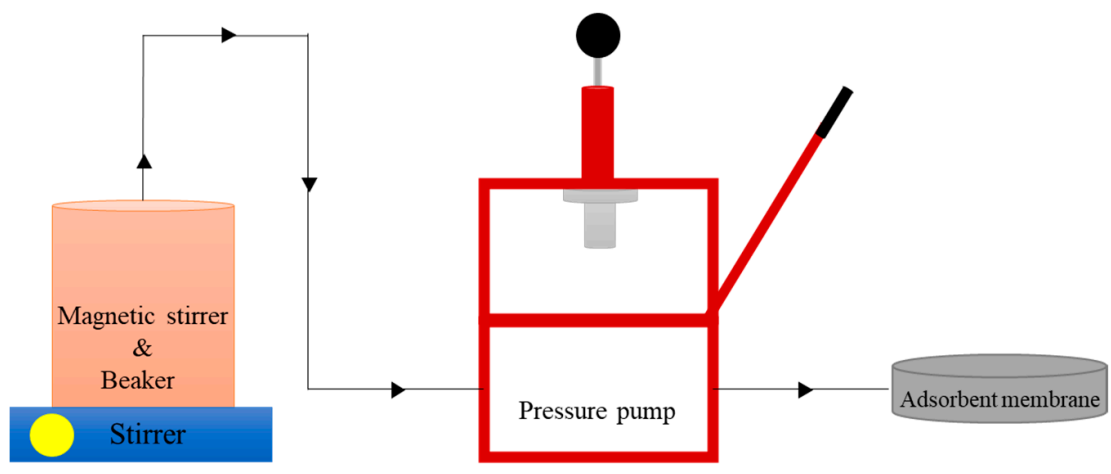

Figure 1. Schematic set-up fabrication of membrane adsorber PEFB.

\subsection{Preparation and Characterisation of Membrane Adsorber PEFB}

The powder was made with hydrochloric acid variations of $0.5,1$, and $1.5 \mathrm{M}$. It was put into each $500 \mathrm{~mL}$ beaker, then mixed with $35 \mathrm{~mL}$ of isopropyl alcohol stirred using a magnetic stirrer at a speed of $600 \mathrm{rpm}$ for $10 \mathrm{~min}$, after which it is filtered. Then, the filter results were added to $3.5 \mathrm{~g}$ of NH4CL as a cationic surfactant, dissolved in $300 \mathrm{~mL}$ of distilled water. The mixture was then stirred with a magnetic stirrer at a speed of $600 \mathrm{rpm}$ for $1 \mathrm{~h}$ to form nano-sized membrane pores (Chowdhury et al., 2006) and filtered using a vacuum pump to leave a solid residue. Solids with variations of $0.5,1$, and $1.5 \mathrm{M}$ in the container were then added respectively to $3.4 \mathrm{~g}$ of PVA and $5 \mathrm{~mL}$ of PEG, and the remaining $8 \mathrm{~mL}$ of filter solution were added gradually until the membrane mixture was solid and fully adhered. The membrane mixture was printed on a membrane mould made of stainless steel with a diameter of $7 \mathrm{~cm}$ and a height of $0.6 \mathrm{~cm}$. Then, the membrane was dried in the sun for about one day. After the upper surface of the membrane was slightly dry, the membrane was then pressed using a hydraulic jack with a pressure of 100 psi.

FTIR (Fourier-Transform Infrared) was used to investigate the chemical properties of silica-carbon xerogels. FTIR spectra data were collected from FTIR type Bruker Alpha. Instrument type: alpha sample compartment RT-DLaTGS accessory: ATR platinum Diamond 1 Relf. The spectra were collected from 30 scans ranging between wavelengths of $500-4000 \mathrm{~cm}^{-1}$. Peak deconvolution of the absorption bands over the region $1300-700 \mathrm{~cm}^{-1}$ was performed with Fityk software using Gaussian line shapes with a least-square fit routine. Peak areas were measured for the normalised spectra using a local baseline [38]. X-ray diffractometer (XRD) with the Copper anode $(\mathrm{Cu}-\mathrm{K} \alpha, \lambda=1.5406)$ was used to identify the formed phases in the membrane adsorber. The morphology of membrane adsorber can be detected through the SEM-EDS method. The sample is placed on the surface of the holder who has been given carbon tape, and then gold is coated on the surface of the model. After coating, the sample is inserted in the sample room, which has been vacuumed first. The selection is analysed using an SEM instrument (HITACHI FLEXSEM 100) to find out the morphology. Nitrogen physisorption analyses were conducted using a Micromeritics TriStar 3000 instrument. The sample was degassed under vacuum for six $h$ at $200{ }^{\circ} \mathrm{C}$. The specific surface area was determined from the Brunauer, Emmett, and Teller (BET) method. The Dubinin-Astakhov and Barrett-Joyner-Halenda methods were taken to determine the average pore sizes of microporous and mesoporous materials, respectively.

\subsection{Biogas Purification Using Membrane Adsorber}

Biogas is flowed from the modified plastic of the temporary biogas reservoir (1) to the compressor to be accommodated. The next biogas from the compressor (2) is pumped to the rotameter (3). The rotameter flow rate is $0.025 \mathrm{~L} / \mathrm{s}$ (Iriani and Heryadi), the rotameter valve is opened to flow biogas into the adsorber column (4) until the biogas passes through the filtration membrane of the adsorber. Furthermore, the biogas that has passed through 
the filtration is directly accommodated in a 0.25-L Tedlar bag (5) and labelled, which is carried out three times with membranes that have been varied. The gas that has been stored in a Tedlar bag is ready to be tested visually with three repetitions of the flame test. The set-up can be seen from Figure 2:

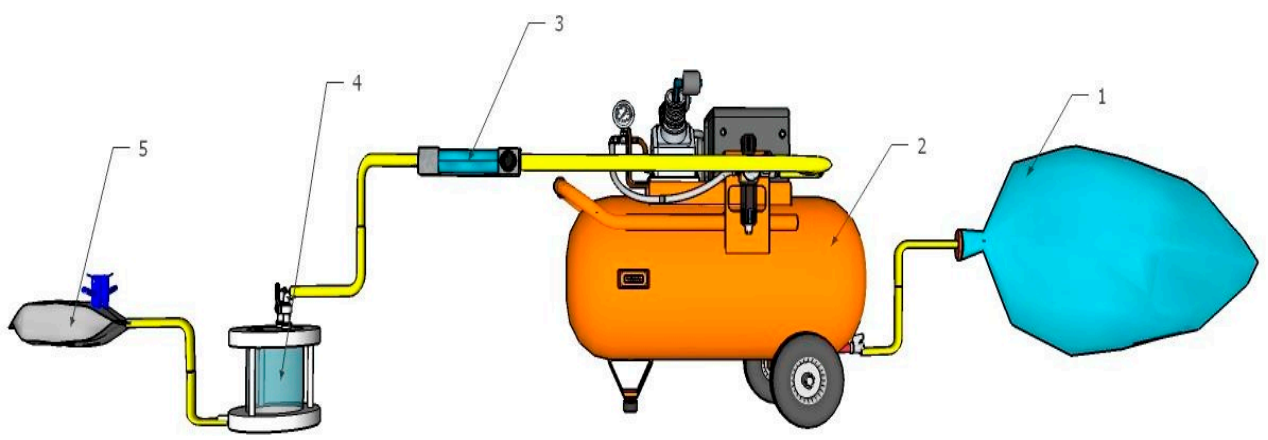

Figure 2. Set-up of biogas purification process.

\section{Results and Discussions}

The FTIR spectra of unmodified membrane adsorber without HCL activation (AC) and activated membrane adsorber using g $0.5(\mathrm{H} 1), 1(\mathrm{H} 2), 1.5(\mathrm{H} 3) \mathrm{M} \mathrm{HCl}$ are presented in Figure 3. It can be seen in Figure 3 that the spectrum of the activated carbon adsorber membrane without the addition of an $\mathrm{HCl}$ activator has a flatter peak than the activated carbon adsorber membrane after the addition of $\mathrm{HCl}$. The elevation found in the $\sim 3382 \mathrm{~cm}^{-1}$ wave represents the $\mathrm{O}-\mathrm{H}$ stretching vibration in the hemicellulose group. Compared to $\mathrm{AC}$, the $\mathrm{O}-\mathrm{H}$ peaks for $\mathrm{H} 1, \mathrm{H} 2$, and $\mathrm{H} 3$ are wider, increasing the $\mathrm{O}-\mathrm{H}$ stretching functional group and water absorption on the surface. This result is in line with a similar study by Tan et al., 2017, which has examined coconut-shell-based activated carbon, where O-H stretching implies the presence of more $\mathrm{O}-\mathrm{H}$ groups from an increase in carboxylic groups on activated carbon that has been modified by $\mathrm{HCl}$ acid [39].

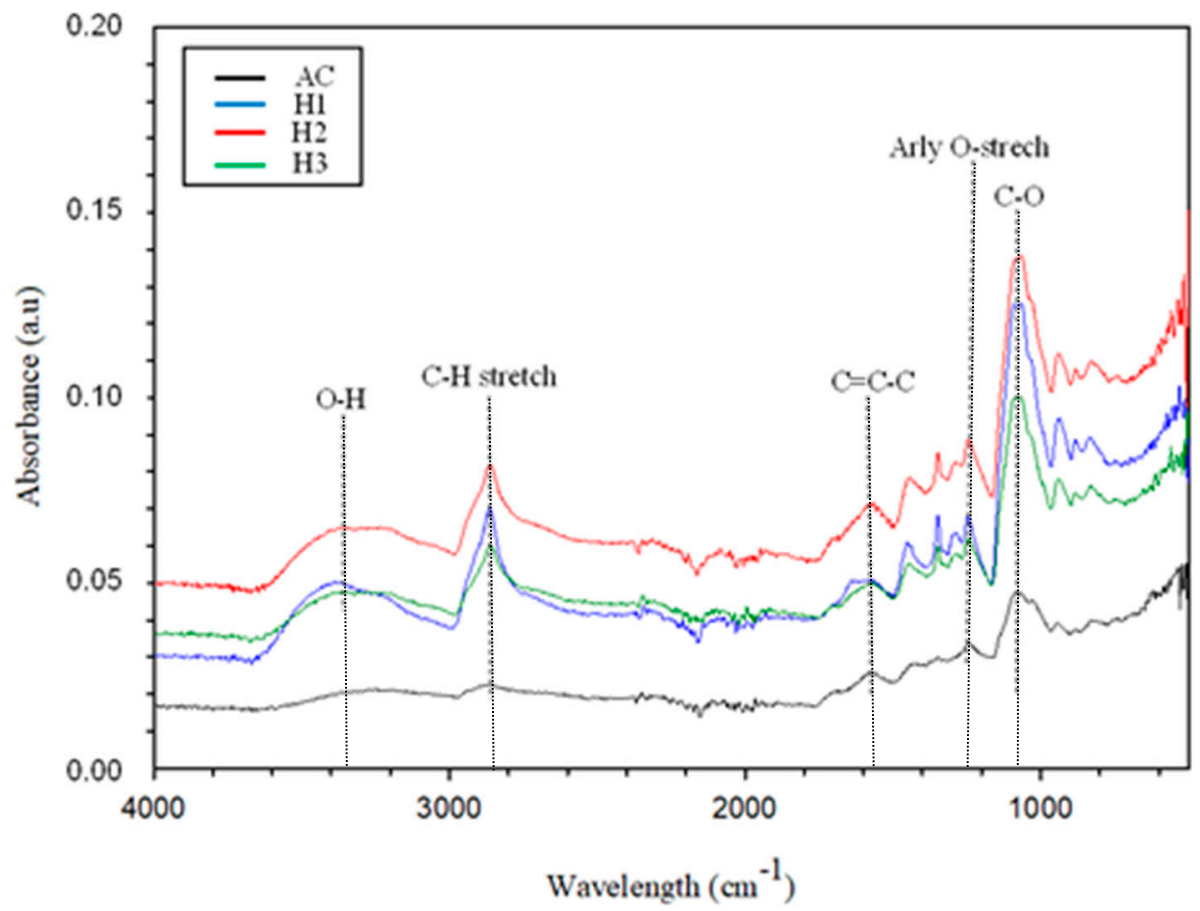

Figure 3. FTIR spectra of adsorber membrane with Activated Carbon (AC), (H1) $\mathrm{HCl} \mathrm{0,5} \mathrm{M;} \mathrm{(H2)} \mathrm{HCl}$ $1 \mathrm{M}$; (H3) $\mathrm{HCl} 1.5 \mathrm{M}$. 
Meanwhile, the wave $\sim 2869 \mathrm{~cm}^{-1}$ corresponds to the C-H stretching mode as a function of the cellulose group. The same trend also shows $\mathrm{H} 1, \mathrm{H} 2$, and $\mathrm{H} 3$ peaks are more prominent. This shows the sample reacts differently in different concentrations of $\mathrm{HCl}$. The functional group $\mathrm{C}=\mathrm{C}-\mathrm{C}$, where the entire waveform is defined as the aromatic ring strain, was observed at $\sim 1607 \mathrm{~cm}^{-1}$. The wavelength at $\sim 1237 \mathrm{~cm}^{-1}$ belongs to the O-aromatic ether strain. The sharp hydroxyl band occurs around $\sim 1077 \mathrm{~cm}^{-1}$. The functional groups in unripe palm empty fruit bunches (PEFB) have a complex and straightforward spectrum. This has been studied further by A. R. Hidayu et al. (2013), which showed an adsorption peak at $3302 \mathrm{~cm}^{-1}$ and identified as $\mathrm{O}-\mathrm{H}$ stretch, which in this case indicated the presence of a bound hydroxide compound in crude palm empty fruit bunches (PEFB) [28]. The distribution of wave crests is also found at a wavelength of $1739 \mathrm{~cm}^{-1}$ which is indicated as a $\mathrm{C}=\mathrm{O}$ functional group, followed by the wavelength in the area of $1216 \mathrm{~cm}^{-1}$ and $1032 \mathrm{~cm}^{-1}$, which also shows the C-O stretch active group (Lu et al., 2007) [40].

The results of the Fityk graph in Figure 4 show differences in adsorber membrane from activated carbon of PEFB before and after the addition of the activator. It can be seen that the highest peak area ratio was obtained at the chemical activation of $0.5 \mathrm{Molar} \mathrm{HCl}$ for the $\mathrm{O}-\mathrm{H}$ functional group. The $\mathrm{O}-\mathrm{H}$ functional group represents the hydroxide [41]. At the same time, the lowest peak area ratio is at 0.0 Molar of physical activation. In comparison, the lowest peak area ratio is on the adsorber membrane with a concentration of $0.0 \mathrm{Molar} \mathrm{HCl}$. The hydroxyl group rises on the carbon because the carboxylic group is added. The $\mathrm{HCl}$ treatment increases the oxygen in the carbon content as well. This leads to an increased adsorption capacity of activated carbon. Instead of forming new functional groups, high concentrations of $\mathrm{HCl}$ convert carbonyl or carboxyl groups into phenol and lactone groups [42]. Previous studies by Hidayu et al., 2013, reported that the specific surface area of activated carbon will increase with increasing acid concentration [28].

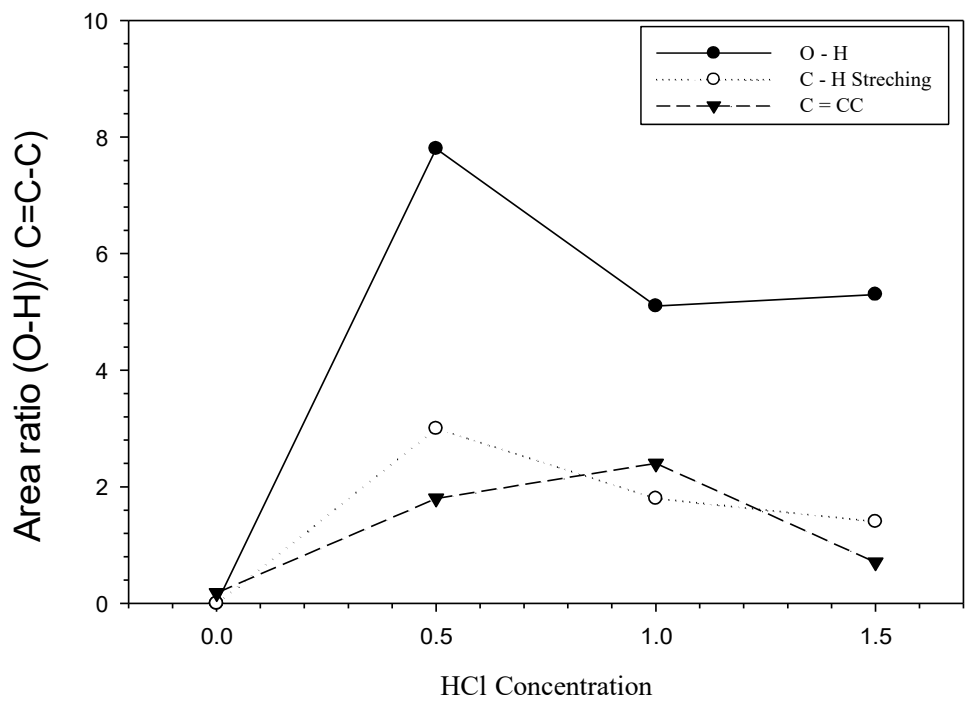

Figure 4. Deconvoluted peak area ratios of activated carbon concentration at adsorber membrane.

Figure 4 shows adsorber membrane from activated carbon of PEFB without chemical activation has the most little $\mathrm{OH}$ stretching strain. In contrast, the adsorber membrane that chemical acids have activated shows that the increase in $\mathrm{OH}$ is caused by the rise in the acid impregnation ratio; the acid contained in PEFB causes a higher carbon combustion rate [29]. This is in line with previous studies, on the outer surface of the $\mathrm{O}-\mathrm{H}$ increasing rapidly, which is a domain factor that affects adsorption efficiency. This occurs because the strain on physical activation is not visible or not formed, while through physicochemical activation, functional groups are included, and the peaks are formed are broader $[34,43]$. However, the ratio of at $1 \mathrm{M} \mathrm{HCl}$ concentration was lower than without activation and the other two $\mathrm{HCl}$ concentrations. 
Based on Table 1, the adsorber membrane from activated carbon of PEFB without chemical activation has a small $\mathrm{O}-\mathrm{H}$ area, compared to the adsorber membrane from activated carbon of PEFB with chemical activation of $\mathrm{HCl}(0.5 ; 1 ; 1.5 \mathrm{M})$. This is because the presence of the $\mathrm{O}-\mathrm{H}$ functional group is caused by the addition of the acid compound-in this study, $\mathrm{HCl}$ [29]. Adsorber membrane from activated carbon of PEFB with variations in the acquisition of chemical concentrations of $\mathrm{HCl}$ has different peak area values for $\mathrm{O}-\mathrm{H}$. The lowest $\mathrm{OH}$ peak area value was found in the $1 \mathrm{M} \mathrm{HCl}$ chemical activation. This was inversely proportional to the $\mathrm{C}=\mathrm{C}-\mathrm{C}$ peak area (aromatic strain ring), where the $1 \mathrm{M} \mathrm{HCl}$ chemical activation sample showed the highest value compared to the activation samples 0 , 0.5 , and $1.5 \mathrm{M} \mathrm{HCl}$. When viewed from the value of the ratio of $\mathrm{O}-\mathrm{H} / \mathrm{C}=\mathrm{C}-\mathrm{C}$, the value of the $1 \mathrm{M} \mathrm{HCl}$ chemical activated PEFB adsorber membrane sample has the lowest number of a 2.13 unit area.

Table 1. Deconvolution of $\mathrm{O}-\mathrm{H} / \mathrm{C}=\mathrm{C}-\mathrm{C}$ concentration.

\begin{tabular}{|c|c|c|c|}
\hline \multirow{2}{*}{$\mathrm{HCl}$ Concentration } & \multicolumn{2}{|c|}{ Area (Qn) } & \multirow{2}{*}{$\begin{array}{l}\text { Area Ratio } \\
\text { H/C }=C-C\end{array}$} \\
\hline & O-H & $\mathrm{C}=\mathrm{C}-\mathrm{C}$ & \\
\hline 0 & 0.01 & 0.18 & 0.00 \\
\hline 0.5 & 7.8 & 1.8 & 4.33 \\
\hline 1 & 5.1 & 2.4 & 2.13 \\
\hline 1.5 & 5.3 & 0.7 & 7.57 \\
\hline
\end{tabular}

The results of the XRD graph shown in Figure 5a above show that the adsorber membrane sample made has an amorphous shape. This is shown from the pattern results on the XRD of the OPEFB adsorber membrane without activation, which obtained an irregular shape, which is an amorphous characteristic. Although no specific peaks were produced, $2 \theta$ angles that could be read were created, namely $14-16^{\circ}, 20-24^{\circ}$ and $25-27^{\circ}$ which were $2 \theta$ angles of legible activated carbon. Based on Figure $5 b$, it can be seen that the $X$-ray diffraction pattern or the increase in the crystallinity value between variations with one another has an insignificant difference, indicating the presence of amorphous carbon that is irregularly stacked by the carbon ring [27]. Thus, the activated carbon contained in the membrane can be identified as carbon with an amorphous structure. There are massive microcrystals in which two distinct diffraction peaks represent the respective diffraction peaks characteristic of the microcrystalline crystalline surface [44].

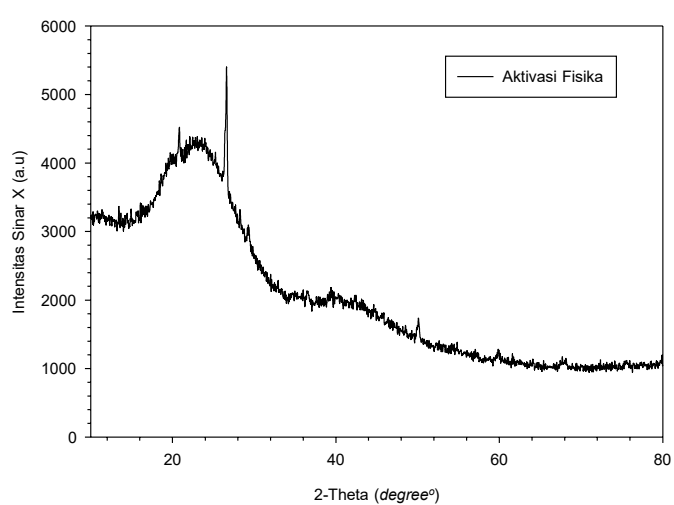

(a)

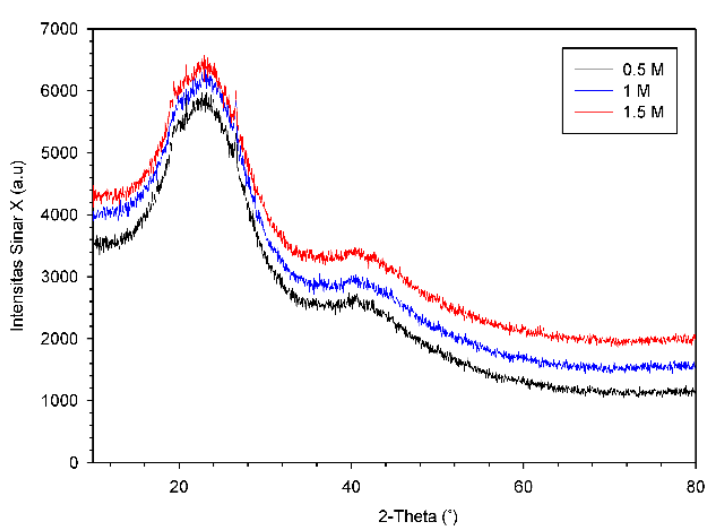

(b)

Figure 5. Diffractogram XRD of (a) unmodified membrane adsorber without HCL activation (AC); (b) activated adsorber membrane using g $0.5(\mathrm{H} 1), 1$ (H2), $1.5(\mathrm{H} 3) \mathrm{M} \mathrm{HCl}$.

The results of SEM characterisation were used to observe the morphology of the adsorber membrane that had been physically activated and physicochemically activated with variations in $\mathrm{HCl}$ content: $0.5,1$, and 1.5 Molar at a magnification of 5000 times shown in Figure 6. 
Figure $6 \mathrm{a}, \mathrm{b}$ show that uneven carbon and polymer content causes polymer clumps so that the membrane does not mix well. The addition of concentration materials gave a significant difference to the mixture of membrane-making materials. From the results of the SEM characteristics, it can be seen that the carbon pores formed on the surface are very irregular, and not too many pores are formed. Based on the XRD test, the adsorber membrane has an amorphous structure. The SEM test on the PEFB adsorber membrane activated a physicschemical concentration of $1.5 \mathrm{M} \mathrm{HCl}$, forming amorphous structured fibre.

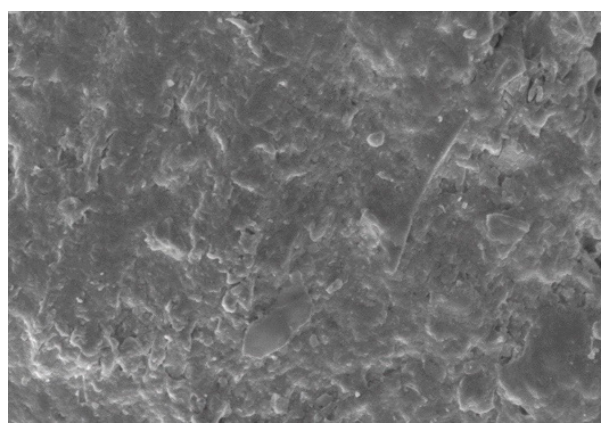

(a)

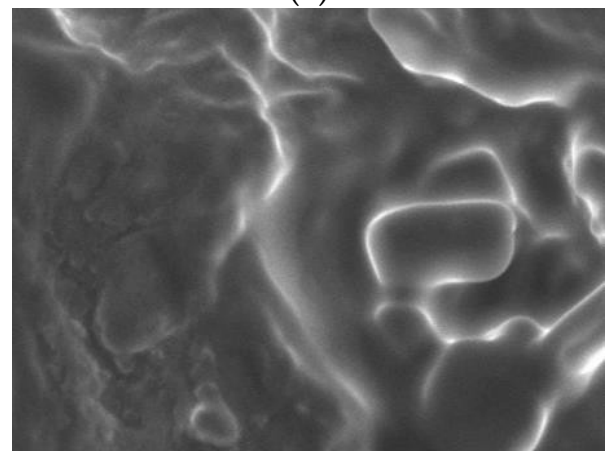

(c)

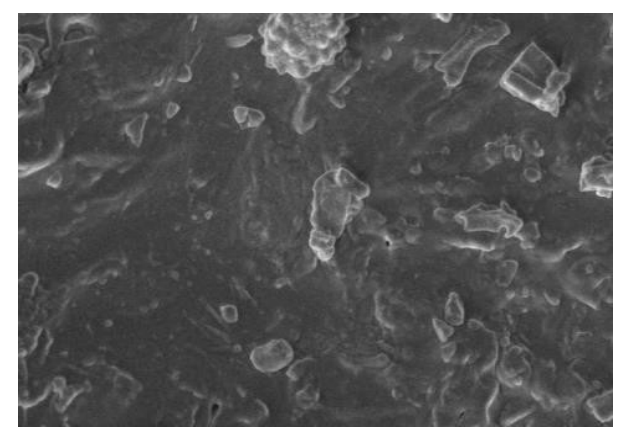

(b)

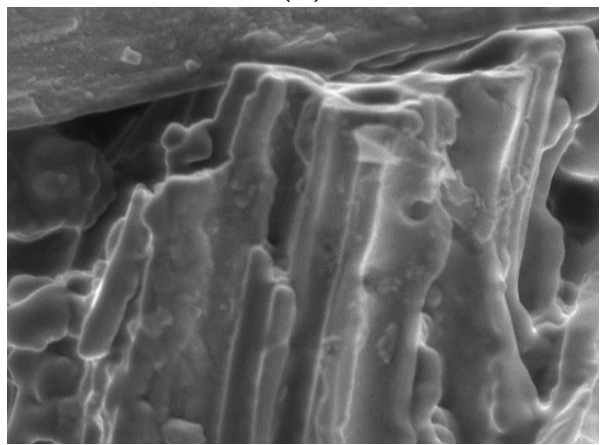

(d)

Figure 6. SEM morphology of: (a) unmodified membrane adsorber without HCL activation (AC); (b) activated membrane adsorber using g $0.5 \mathrm{M}$; (c) $1 \mathrm{M}$; (d) $1.5 \mathrm{M} \mathrm{HCl}$.

In the International Union of Pure and Applied Chemistry (IUPAC) classification, pores are micropores ( $50 \mathrm{~nm}$ diameter). This classification is essential because most molecules of gaseous pollutants vary from $0.4 \mathrm{~nm}$ to $0.9 \mathrm{~nm}$ in diameter. Gas-phase activated carbons usually consist predominantly of micropores, whilst liquid-phase activated carbons have significant mesopores because of the larger sizes of liquid molecules. Figure 7 shows the adsorption-desorption process of nitrogen from adsorbing activated carbon OPEFB, which belongs to the type 1 isotherm. Type 1 isotherm causes a flat or almost flat-convex curve where the adsorption isotherm directly intersects the line $\mathrm{P} / \mathrm{Po}=1$.

The surface area of all test variables on the PEFB adsorber membrane is given in Table 2. The highest surface area calculated using the BET method was found in the variable with a $0.5 \mathrm{M} \mathrm{HCl}$ activator concentration of $0.5345 \mathrm{~m}^{2} / \mathrm{g}$. Inversely proportional to the pore volume and the average pore diameter produced, the variable with $0.0 \mathrm{M} \mathrm{HCl}$ activator concentration has the most significant values, namely $0.00878 \mathrm{~cm}^{3} \mathrm{~g}^{-1}$ and $130.13 \mathrm{~nm}$. In this study, the OPEFB adsorber membrane with an activating agent concentration of $0.5 \mathrm{M}$ had the lowest pore volume and average pore diameter compared to other variables due to the presence of acidic substances that inhibited the formation of pores, especially micropores. The surface area and pore volume values obtained can be said to be relatively small. This can be caused by a polymer material, which only functions as an adhesive and causes clumping to inhibit pores' formation. 


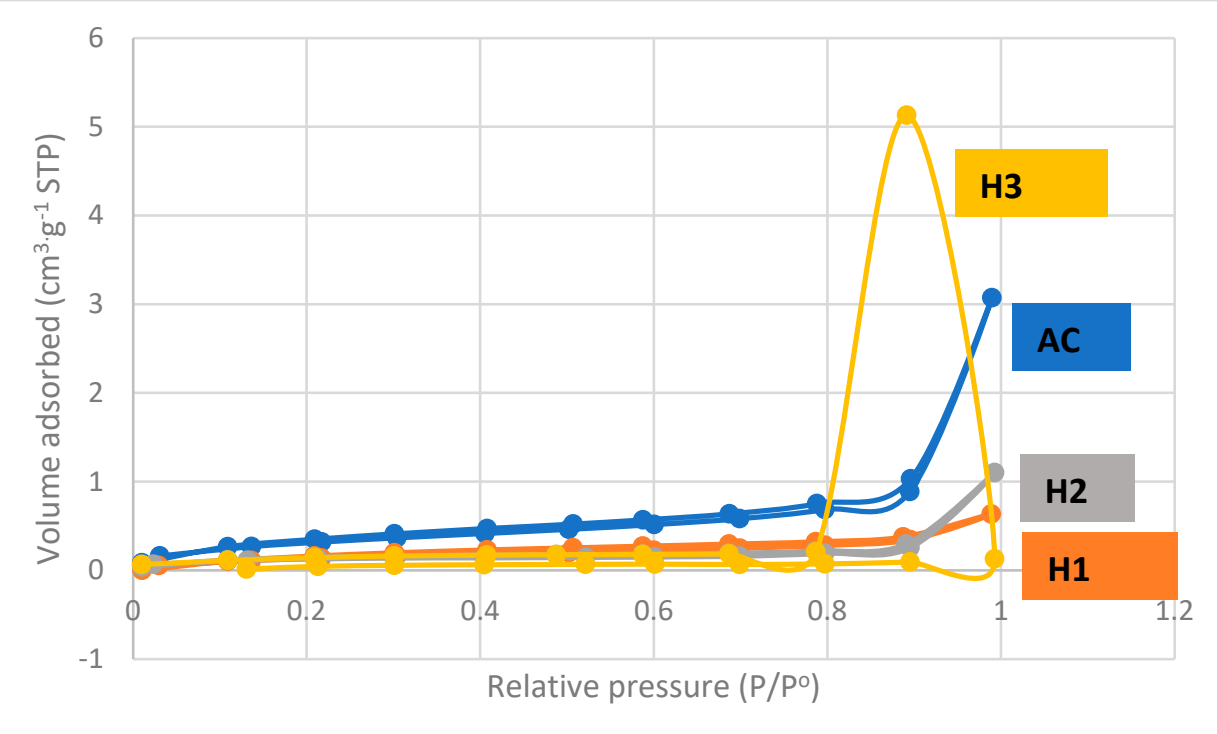

Figure 7. Plots of biogas isotherm data of unmodified membrane adsorber without HCL activation (AC) and activated membrane adsorber using g $0.5(\mathrm{H} 1), 1(\mathrm{H} 2), 1.5(\mathrm{H} 3) \mathrm{M} \mathrm{HCl}$.

Table 2. Surface properties of palm empty fruit bunch membrane adsorber.

\begin{tabular}{cccc}
\hline Concentration (M) & SBET $\left(\mathbf{m}^{\mathbf{2}} \mathbf{g}^{-\mathbf{1}}\right)$ & Pore Volume $\left(\mathbf{c m}^{\mathbf{3}} \mathbf{g}^{-\mathbf{1}}\right)$ & $\begin{array}{c}\text { Average Pore } \\
\text { Diameter (nm) }\end{array}$ \\
\hline 0 & 0.2699 & 0.00878 & 130.12732 \\
0.5 & 0.5345 & 0.000983 & 7.34468 \\
1 & 0.4387 & 0.001705 & 15.54718 \\
1.5 & 0.4001 & 0.001484 & 14.83716 \\
\hline
\end{tabular}

Based on Figure 8, visible changes in the colour of the flame indicate an increase in performance in biogas which has been purified using a membrane. Qualitatively, the pure biogas flame test results are predominantly yellowish red, which indicates that pure biogas has less $\mathrm{CH}_{4}$ content than $\mathrm{CO}_{2}$ and other impurities, which have a higher value. The colour changes on activation of the physicochemical variation of $\mathrm{HCl}$ in Figure 8 look very similar in terms of the colour produced. In the physicochemical variation with a content of $0.5,1$, and $1.5 \mathrm{M}$, the dominant flame colour is bright blue compared to physical activation. The chemical activation of $1 \mathrm{M} \mathrm{HCl} \mathrm{looks} \mathrm{fire-coloured} \mathrm{with} \mathrm{a} \mathrm{clear} \mathrm{blue} \mathrm{spectrum} \mathrm{compared}$ to 0.5 and $1.5 \mathrm{M}$ and looks stable. Flames with a dark blue spectrum have a high calorific value, and the burning of biogas with blue flames is the result of methane gas. The biogas flame test showed that the oil palm empty fruit bunch adsorber membrane has potential for application in gas purification, although the BET test results show the formation of a pore size that is not too large. 


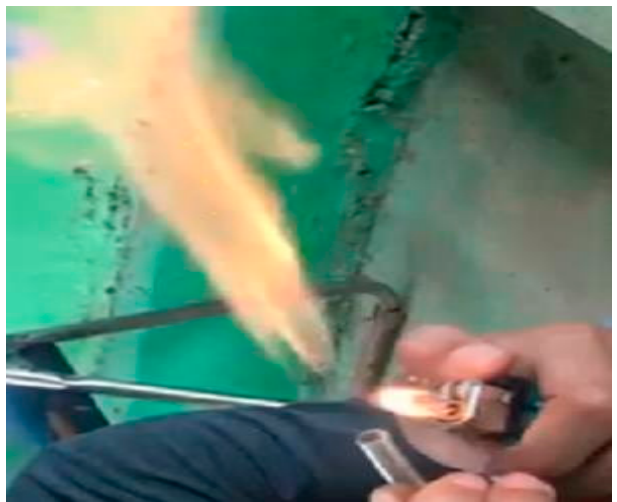

(a)

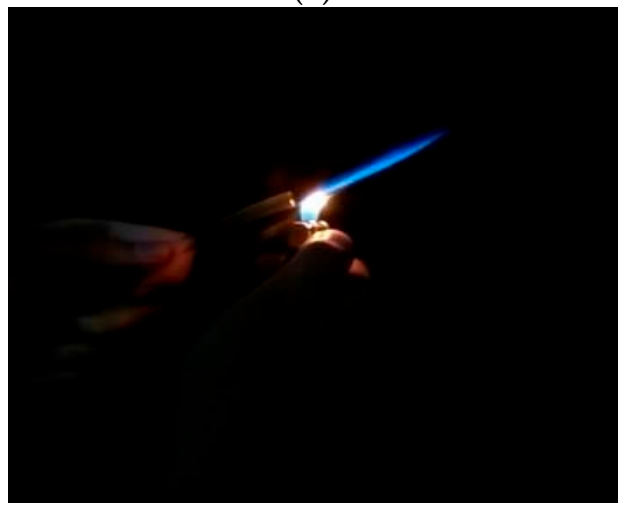

(c)

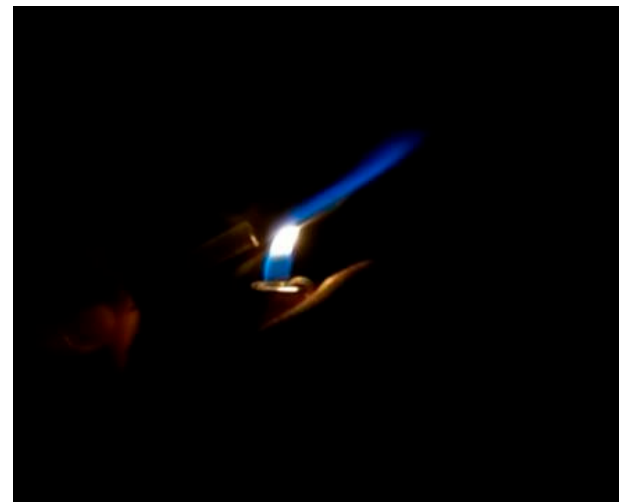

(b)

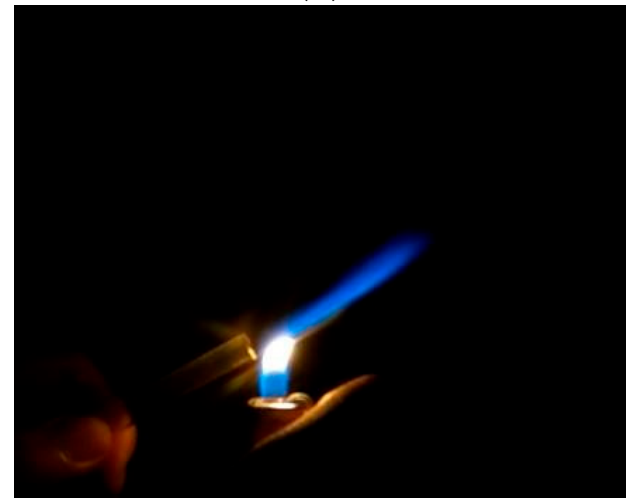

(d)

Figure 8. Flame test (a) without using a membrane, (b) $0.5 \mathrm{M} \mathrm{HCl}$, (c) $1 \mathrm{M} \mathrm{HCl}$, and (d) $1.5 \mathrm{M} \mathrm{HCl}$ PEFB adsorber membrane.

\section{Conclusions}

A palm empty fruit bunch adsorber membrane has been successfully fabricated through chemical activation and characterised using FTIR test, XRD test, and membrane morphology using SEM test and nitrogen absorption test using BET method. In the FTIR test, there are functional groups, namely $\mathrm{O}-\mathrm{H} ; \mathrm{C}-\mathrm{H}$ stretch; $\mathrm{C}=\mathrm{C}-\mathrm{C}$; Arly O-Strech; C-O, which indicates that activated carbon has been formed. The most significant number of activated carbon group formations occurred in the addition of a $0.5 \mathrm{M} \mathrm{HCl}$ activator. Based on the XRD test, the adsorber membrane has an amorphous structure. Based on the SEM test on PEFB, the adsorber membrane activated by physicochemical concentration of $1.5 \mathrm{M} \mathrm{HCl}$ has a fibre shape and asymmetric design. XRD and SEM tests showed that the adsorber membrane has a slightly amorphous structure that forms fibres and an asymmetrical structure with a dominant crystal shape. Judging from the surface area and pore volume in the nitrogen isotherm absorption test, all the variables tested showed small values. This is probably caused by the addition of PAV and PEG polymer materials as adhesives which are still not appropriate. The surface area of the nitrogen isotherm is found in the variable with a concentration of $0.5 \mathrm{M} \mathrm{HCl}$, which is $0.5345 \mathrm{~m}^{2} / \mathrm{g}$. As for the size of the pore volume and the average pore diameter, the most significant results were obtained in the variable with an $\mathrm{HCl}$ concentration of $0.0 \mathrm{M}$. The most significant surface area test values were $0.5 \mathrm{M}$, respectively; $1 \mathrm{M} ; 1.5 \mathrm{M}$; and $0.0 \mathrm{M}$. For the results of the pot volume and average pore diameter, respectively, the most significant yield was $0.0 \mathrm{M} ; 1 \mathrm{M}$; $1.5 \mathrm{M}$; and $0.5 \mathrm{M}$. 
Author Contributions: Conceptualisation, N.H. (Nur Hidayah), M.E., A.A., D.G.L.P. and H.R.A.; methodology, A.A., D.G.L.P., H.R.A., N.H. (Nurul Huda) and A.R.; validation, N.H. (Nur Hidayah), M.E. and A.R.; investigation, A.A., D.G.L.P. and H.R.A.; resources, P.V.D.; data curation, N.H. (Nurul Huda), A.A., D.G.L.P. and H.R.A.; writing-original draft preparation, N.H. (Nurul Huda), A.A., D.G.L.P. and H.R.A.; writing-review and editing, N.H. (Nur Hidayah), M.E. and A.R.; visualisation, I.S.; supervision, M.E.; project administration, N.H. (Nurul Huda); funding acquisition, N.H. (Nur Hidayah). All authors have read and agreed to the published version of the manuscript.

Funding: This research was funded by the "Directorate General of Higher Education, Ministry of Education, Culture, Research, and Technology" and "The APC was funded by Applied Research Collaboration Between Universities Grant 2020-2021".

Institutional Review Board Statement: Not applicable.

Informed Consent Statement: Not applicable.

Data Availability Statement: Not applicable.

Acknowledgments: The authors give thanks to the Materials and Membranes Research Group (M2ReG) of Lambung Mangkurat University for support, facilities, and sample characterisation at the Research Center for Biomaterials, Indonesian Institute of Sciences; at Energy and Environment Laboratory, ITS; Integrated Research and Testing Laboratory, Gajah Mada University. Muthia Elma thanks to PTUPT 2021-2023, Penelitian Dasar 2021-2022 and WCR 2021-2023 DRPM DIKTI National Innovation and Research Agency Republic of Indonesia.

Conflicts of Interest: The authors declare no conflict of interest.

\section{References}

1. Pertiwiningrum, A.; Dwi Koranto, C.A.; Wuri, M.A. Renewable Energy of Biogas Through Integrated Organic Cycle System in Tropical System. IntechOpen 2018, 74497, 99-117. [CrossRef]

2. Muñoz, R.; Meier, L.; Diaz, I.; Jeison, D. A review on the state-of-the-art of physical/chemical and biological technologies for biogas upgrading. Rev. Environ. Sci. Biotechnol. 2015, 14, 727-759. [CrossRef]

3. Axelsson, L.; Franzén, M.; Ostwald, M.; Berndes, G.; Lakshmi, G.; Ravindranath, N.H. Perspective: Jatropha cultivation in southern India: Assessing farmers' experiences. Biofuels Bioprod. Biorefining 2012, 6, 246-256. [CrossRef]

4. Petersson, A.; Holm-nielsen, J.B.; Baxter, D. Biogas upgrading technologies- developments and innovations. IEA Bioenergy 2009, 20,1-19.

5. Ryckebosch, E.; Drouillon, M.; Vervaeren, H. Techniques for transformation of biogas to biomethane. Biomass Bioenergy 2011, 35, 1633-1645. [CrossRef]

6. Susanto, H.; Wijaya, W.; Widiasa, I.N. Modifikasi Karbon Aktif Sebagai Adsorben Untuk Pemurnian Biogas. Teknik 2013, 34, 4-8. [CrossRef]

7. McKinsey, S.Z. Removal of Hydrogen Sulfide from Biogas Using Cow-Manure Compost. Cornell Univ. 2003, 1-104. Available online: http:/ / citeseerx.ist.psu.edu/viewdoc/download?doi=10.1.1.470.2484\&rep=rep1\&type=pdf (accessed on 18 November 2021).

8. Hidalgo, D.; Sanz-Bedate, S.; Martín-Marroquín, J.M.; Castro, J.; Antolín, G. Selective separation of $\mathrm{CH}_{4}$ and $\mathrm{CO}_{2}$ using membrane contactors. Renew. Energy 2020, 150, 935-942. [CrossRef]

9. Angelidaki, I.; Xie, L.; Luo, G.; Zhang, Y.; Oechsner, H.; Lemmer, A.; Munoz, R.; Kougias, P.G. Biogas Upgrading: Current and Emerging Technologies, 2nd ed.; Elsevier Inc.: Amsterdam, The Netherlands, 2019; ISBN 9780128168561.

10. Baena-Moreno, F.M.; Rodríguez-Galán, M.; Vega, F.; Vilches, L.F.; Navarrete, B. Review: Recent advances in biogas purifying technologies. Int. J. Green Energy 2019, 16, 401-412. [CrossRef]

11. Chen, X.Y.; Vinh-Thang, H.; Ramirez, A.A.; Rodrigue, D.; Kaliaguine, S. Membrane gas separation technologies for biogas upgrading. RSC Adv. 2015, 5, 24399-24448. [CrossRef]

12. Zhou, K.; Chaemchuen, S.; Verpoort, F. Alternative materials in technologies for Biogas upgrading via $\mathrm{CO}_{2}$ capture. Renew. Sustain. Energy Rev. 2017, 79, 1414-1441. [CrossRef]

13. Mutia, E. Proses Pemisahan Menggunakan Teknologi Membran; Lambung Mangkurat University Press: Kalimantan Selatan, Indonesia, 2019; Volume 53, ISBN 978-857-811-079-6.

14. Li, Y.; Wang, L.; Hu, X.; Jin, P.; Song, X. Surface modification to produce superhydrophobic hollow fiber membrane contactor to avoid membrane wetting for biogas purification under pressurized conditions. Sep. Purif. Technol. 2018, 194, 222-230. [CrossRef]

15. Jin, P.; Huang, C.; Li, J.; Shen, Y.; Wang, L. Surface modification of poly(Vinylidene fluoride) hollow fibre membranes for biogas purification in a gas-liquid membrane contactor system. R. Soc. Open Sci. 2017, 4, 171321. [CrossRef] [PubMed]

16. Žák, M.; Bendová, H.; Friess, K.; Bara, J.E.; Izák, P. Single-step purification of raw biogas to biomethane quality by hollow fiber membranes without any pretreatment-An innovation in biogas upgrading. Sep. Purif. Technol. 2018, 203, 36-40. [CrossRef]

17. He, Q.; Yu, G.; Yan, S.; Dumée, L.F.; Zhang, Y.; Strezov, V.; Zhao, S. Renewable CO2 absorbent for carbon capture and biogas upgrading by membrane contactor. Sep. Purif. Technol. 2018, 194, 207-215. [CrossRef] 
18. Harasimowicz, M.; Orluk, P.; Zakrzewska-Trznadel, G.; Chmielewski, A.G. Application of polyimide membranes for biogas purification and enrichment. J. Hazard. Mater. 2007, 144, 698-702. [CrossRef]

19. Saiful, S. Performance of Mixed Matrix Membrane Adsorbers for Lysozyme Separation. J. Rekayasa Kim. Lingkung. 2011, 8, 29-34.

20. Boi, C.; Malavasi, A.; Carbonell, R.G.; Gilleskie, G. A direct comparison between membrane adsorber and packed column chromatography performance. J. Chromatogr. A 2020, 1612, 460629. [CrossRef]

21. Indonesia B.P.S. Indonesian Oil Palm Statistic 2019; Perkebunan, S.S.T., Ed.; Badan Pusat Statistik: Jakarta, Indonesia, 2019; ISBN 1978-9947.

22. Ayuni, S.T.; Larasaty, P.; Anam, C.; Riyadi, A.; Hastuti, A.; Kurniasih, A.; Saputri, V.G.; Pratiwi, A.I.; Meilaningsih, T. Laporan Perekonomian Global. CBPS RI/BPS-Statistics Indonesia, Jakarta. 2020. Available online: www.bi.go.id (accessed on 18 November 2021).

23. Sulihatimarsyila, N.U.R.; Wafti, A.B.D.; Lik, H.; Lau, N.; Loh, S.O.H.K.; Aziz, A.A.; Rahman, Z.A.B.; May, C.Y. Activated Carbon From Oil Palm Biomass as Potential Adsorbent for Palm Oil Mill Effluent Treatment. J. Oil Palm Res. 2017, $29,278-290$.

24. Wang, Y.; Pan, J.; Li, Y.; Zhang, P.; Zhang, X.; Li, M.; Zheng, H.; Sun, Y.; Wang, H.; Du, Q. Preparation and Characterization of Activated Carbon from Oil-palm Fiber and Its Evaluation for Methylene Blue Adsorption. Mater. Tehnol. 2021, 55, 449-457. [CrossRef]

25. Ooi, C.; Lee, T.; Pung, S.; Yeoh, F. Activated Carbon Fiber Derived From Single Step Carbonization-Activation Process. ASEAN Eng. J. 2013, 4, 40-50.

26. Gaol, M.R.L.L.; Sitorus, R.; Yanthi, S.; Surya, I.; Manurung, R. Pembuatan Selulosa Asetat Dari $\alpha$-Selulosa Tandan Kosong Kelapa Sawit. J. Tek. Kim. USU 2013, 2, 33-39. [CrossRef]

27. Rani, N.H.A.; Mohamad, N.F.; Matali, S.; Sharifah Aishah, S.A.S. Preparation and characterization of activated carbon made from oil palm empty fruit bunch. Key Eng. Mater. 2014, 594-595, 44-48. [CrossRef]

28. Hidayu, A.R.; Mohamad, N.F.; Matali, S.; Sharifah, A.S.A.K. Characterization of activated carbon prepared from oil palm empty fruit bunch using BET and FT-IR techniques. Procedia Eng. 2013, 68, 379-384. [CrossRef]

29. Guo, J.; Gui, B.; Xiang, S.X.; Bao, X.T.; Zhang, H.J.; Lua, A.C. Preparation of activated carbons by utilizing solid wastes from palm oil processing mills. J. Porous Mater. 2008, 15, 535-540. [CrossRef]

30. Zamani, S.A.; Yunus, R.; Samsuri, A.W.; Salleh, M.A.M.; Asady, B. Removal of Zinc from Aqueous Solution by Optimized Oil Palm Empty Fruit Bunches Biochar as Low Cost Adsorbent. Bioinorg. Chem. Appl. 2017, 2017, 7914714. [CrossRef]

31. Septevani, A.A.; Rifathin, A.; Sari, A.A.; Sampora, Y.; Ariani, G.N.; Sondari, D. Oil palm empty fruit bunch-based nanocellulose as a super-adsorbent for water remediation. Carbohydr. Polym. 2020, 229, 115433. [CrossRef]

32. Elias, M.A.; Hadibarata, T.; Sathishkumar, P. Modified oil palm industry solid waste as a potential adsorbent for lead removal. Environ. Chem. Ecotoxicol. 2021, 3, 1-7. [CrossRef]

33. Hendrawan, Y.; Nurseta, D.Y.; Utami, R.; Trilaksana, M.I.A.; Sumarlan, S.H.; Wibisono, Y. Effect of carbonisation temperature and activating agents on the characteristics of activated carbon produced from oil palm empty fruit bunch. IOP Conf. Ser. Earth Environ. Sci. 2021, 733, 012004. [CrossRef]

34. Ooi, C.H.; Cheah, W.K.; Sim, Y.L.; Pung, S.Y.; Yeoh, F.Y. Conversion and characterization of activated carbon fiber derived from palm empty fruit bunch waste and its kinetic study on urea adsorption. J. Environ. Manag. 2017, 197, 199-205. [CrossRef]

35. Hidayat, A.; Sutrisno, B. Comparison on pore development of activated carbon produced by chemical and physical activation from palm empty fruit bunch. IOP Conf. Ser. Mater. Sci. Eng. 2016, 162, 012008. [CrossRef]

36. Wibisono, Y.; Amanah, A.; Sukoyo, A.; Anugroho, F.; Kurniati, E. Activated Carbon Loaded Mixed Matrix Membranes Extracted from Oil Palm Empty Fruit Bunches for Vehicle Exhaust Gas Adsorbers Extracted from Oil Palm Empty Fruit Bunches for Vehicle Exhaust Gas Adsorbers. Evergr. Jt. J. Nov. Carbon Resour. Sci. Green Asia Strateg. 2021, 8, 593-600.

37. Said, S.M.; Subriyer, N.; Priadi, D.P. The Effect of Addition of Activated Carbon Made from Oil Palm Empty Fruit Bunch and Iron Powder on Ceramic Membrane Characteristics. In Proceedings of the 7th Annual Basic Science International Conference, Malang, Indonesia, 7-8 March 2017; Volume 2, p. 278.

38. Elma, M.; Sumardi, A.; Paramita, A.; Rahma, A.; Lestari, A.E.; Yanto, D.H.Y.; Hadi, S.; Assyaifi, Z.L.; Raharjo, Y. Physicochemical properties of mesoporous organo-silica xerogels fabricated through organo catalyst. Membranes 2021, 11, 607. [CrossRef] [PubMed]

39. Tan, I.A.W.; Abdullah, M.O.; Lim, L.L.P.; Yeo, T.H.C. Surface Modification and Characterization of Coconut Shell-Based Activated Carbon Subjected to Acidic and Alkaline Treatments. J. Appl. Sci. Process Eng. 2017, 4, 186-194.

40. Lu, G.Q.; Diniz da Costa, J.C.; Duke, M.; Giessler, S.; Socolow, R.; Williams, R.H.; Kreutz, T. Inorganic membranes for hydrogen production and purification: A critical review and perspective. J. Colloid Interface Sci. 2007, 314, 589-603. [CrossRef] [PubMed]

41. Yavari, S.; Malakahmad, A.; Sapari, N.B.; Yavari, S. Synthesis optimization of oil palm empty fruit bunch and rice husk biochars for removal of imazapic and imazapyr herbicides. J. Environ. Manage. 2017, 193, 201-210. [CrossRef]

42. Chen, J.P.; Wu, S. Acid/Base-Treated Activated Carbons: Characterization of Functional Groups and Metal Adsorptive Properties. Langmuir 2004, 20, 2233-2242. [CrossRef] [PubMed]

43. Prahas, D.; Kartika, Y.; Indraswati, N.; Ismadji, S. Activated carbon from jackfruit peel waste by H3PO4 chemical activation: Pore structure and surface chemistry characterization. Chem. Eng. J. 2008, 140, 32-42. [CrossRef]

44. Tang, Y.B.; Liu, Q.; Chen, F.Y. Preparation and characterization of activated carbon from waste ramulus mori. Chem. Eng. J. 2012, 203, 19-24. [CrossRef] 